\title{
PREPARATION OF COLD CREAM AGAINST CLINICAL PATHOGEN USING CARALLUMA ADSCENDENS VAR. ATTENUATA
}

\author{
SUNDAR MADASAMY ${ }^{1}$, SURESH SUNDAN ${ }^{2}$, LINGAKUMAR KRISHNASAMY ${ }^{1 *}$ \\ ${ }^{1}$ Centre for Research and Postgraduate Studies in Botany, Ayya Nadar Janaki Ammal College (Autonomous) Sivakasi, Tamil Nadu, India. \\ ${ }^{2}$ Department of Botany, Directorate of Distance Education, Madurai Kamaraj University, Madurai, Tamil Nadu, India. \\ Email: krish.lingakumar@gmail.com
}

Received: 20 April 2020, Revised and Accepted: 29 June 2020

ABSTRACT

Objective: A simple formulation of cold cream from methanolic extract Caralluma adscendens var. attenuata (MECA) and their antimicrobial activity was tested against various clinical pathogens, namely, Escherichia coli, methicillin-resistant Staphylococcus aureus, vancomycin-resistant Enterococcus faecium, and Candida albicans.

Methods: Methanol extract of these plant extract was prepared by the Soxhlet method. We analyzed phytochemical nature of theses plant, and subsequently, a cream was formulated cold-cream $C$. adscendens var. attenuata (FCA) different concentration such as FCA 50 mg, FCA 100 mg, and FCA $200 \mathrm{mg}$. In the present study, aimed to the antimicrobial activity of cold cream was measured by agar well diffusion method, and standard antibiotic Neosporin (market available) cream was used as positive control and dummy cold cream (without-MECA) were used as the negative control.

Results: Phytochemical screening showed that the plant extracts were found a rich source of secondary metabolites. For more, the efficacy of cold cream from MECA extracts to against the clinical pathogen. Positive control Neosporin and 200 mg FCA cream was a highly significant difference in the zone of inhibition when compared to dummy cream. The $200 \mathrm{mg}$ FCA was activity against Escherichia coli, methicillin-resistant Staphylococcus aureus, vancomycin-resistant E. faecium, and C. albicans highly significantly difference (p<0.05) compared FCA 50 mg and FAC 100 mg creams.

Conclusion: The results from this study suggested that the cold cream form base of MECA crude had antimicrobial activity in the different clinical pathogen. They could be used as an alternative source to conventional antimicrobial agents for the treatment of pathological infection.

Keywords: Formulation, Cold cream, Caralluma adscendens var. attenuata, Neosporin, Antibacterial activity.

(C) 2020 The Authors. Published by Innovare Academic Sciences Pvt Ltd. This is an open access article under the CC BY license (http://creativecommons. org/licenses/by/4. 0/) DOI: http://dx.doi.org/10.22159/ajpcr.2020.v13i9.37976

\section{INTRODUCTION}

Every plant possesses medicinal properties, in today's context of medical field plants, the contribution is very essential, and most of the countries had interested to that ancient medicinal plants have reinvestigate to the discovery of active compounds and it is too established for disease curative [1]. On the other hand, diseases are more abundant in the world; diseases causing by the agents called pathogens such as bacteria, fungi, and virus. These pathogens induced diseases by human being were divided that mild; severe infection; and finally death [2]. During the past few decades, the global interest in these studies of pathological skin diseases causing by bacteria, fungi, and other organisms, which are not easily differentiated and very complicated to clinically challenges [3]. Some of the Gram-negative and Gram-positive bacteria had grown skin wound, and it will lead the sever effect, at the same time treatment of multidrug-resistant had against pathogen [4]. However, natural products of phytocompounds have the potential to boost resistant the host-pathogen, and it possesses the antibacterial, antifungal properties [5]. Further, the herbal creambased phytocompounds had adverse effects son resistant to pathological infection. Caralluma genus widely distributed in the worldwide 122 taxa and belongs to the family (Apocynaceae) [6]. Caralluma attenuata had rich secondary phytocompounds such as alkaloids, steroids, and terpenoids [7]. We in this study were examined the phytoconstituent nature of this plant using qualitative analysis, and then we formulated cold cream by methanolic extract Caralluma adscendens var. attenuata (MECA) crude extract. The purpose of this study is to evaluate the formulated cold cream of antimicrobial activity against Escherichia coli, methicillin-resistant Staphylococcus aureus (MRSA), vancomycin-resistant Enterococcus faecium (VREF), and Candida albicans an under the control of laboratory condition.

\section{METHODS}

\section{Preparation of extract}

Caralluma adscendens var. attenuata collected from around Sivakasi area Tamil Nadu, India, and it was chopped into small pieces and dried at room temperature ground into a fine powder and was placed into the Soxhlet apparatus. About $100 \mathrm{~g}$ of powdered material was subjected to methanol (AR, grade) extraction in $600 \mathrm{ml}$ in $95 \%$ using a Soxhlet apparatus for $6 \mathrm{~h}$. Solvents thus obtained were evaporated under reduced pressure at $55-60^{\circ} \mathrm{C}$ and dried in a vacuum. The residues were filtered and concentrated to dry masses by vacuum distillation. Evaporate this extract to get the semisolid mass.

Phytochemical screening and formulation antimicrobial cold cream

The extract MECA crud was analyses the phytoconstituents, namely, alkaloids, carbohydrates, glycosides, proteins, flavonoids, steroids, triterpenoids, and phenolic compounds using qualitative suitable test $[8,9]$. Then, we formulated herbal cold cream by MECA crude.

\section{Wagner's test (alkaloids)}

About $10 \mathrm{mg}$ of extract was taken, and few drops of Wagner's reagent were added, and the formation of a reddish-brown precipitate to indicates the presence of alkaloids.

\section{Shinoda test (flavonoids)}

Ten milligram of extract was added to a pinch of magnesium turnings, and 1-2 drops of concentrated hydrochloric acid were added. Formation of pink color indicates the presence of flavonoids. 
Lead acetate test (phenol and tannins)

Ten milligram of extract was taken, and $0.5 \mathrm{ml}$ of $1 \%$ lead acetate solution was added, and the formation of a precipitate indicates the presence of tannins and phenolic compounds.

\section{Salkowski's test (Steroids)}

Five milligram of extract was dissolved in $2 \mathrm{ml}$ of chloroform, and an equal volume of concentrated sulfuric acid was added along the sides of the test tube. The upper layer turns red, and the lower layer turns yellow with green fluorescence, indicating the presence of the steroids and sterols compound in the extract.

\section{Fehling's test (Carbohydrates)}

Five milliliter of Fehling's solution was added to $0.5 \mathrm{mg}$ of extract and boiled in a water bath. The formation of a yellow or red precipitate indicates the presence of reducing power

\section{Test for terpenoids}

An amount of $0.8 \mathrm{~g}$ of the selected plant sample was taken in a test tube, then poured $10 \mathrm{ml}$ of methanol in it, shaken well, and filtered to take 5 $\mathrm{ml}$ extract of plant sample. Then, $2 \mathrm{ml}$ of chloroform were mixed in the extract of selected plant sample, and $3 \mathrm{ml}$ of sulfuric acid were added in the sample extract chosen. Formation of reddish-brown color indicates the presence of terpenoids in the selected plants.

\section{Test for cardiac glycosides}

Two milliliter of extract was added with $2 \mathrm{ml}$ glacial acetic acid followed by one drop of $5 \% \mathrm{FeCl}_{3}$ from the side of the test tube. A reddish-brown ring appears at the junction of the two liquid layers indicated the presence of cardiac glycosides.

\section{Test for Phlobatannins}

The plant extract was mixed with distilled water in a test tube, then shake it well and filtered to take plant extract. Plant extract, $1 \%$ aqueous hydrochloric acid was added, and it was boiled with the help of hot plate stirrer. Formation of red-colored precipitate confirmed a positive result.

\section{The herbal antimicrobial cream formulation}

The cream is naturally based in water in oil emulsion, and three different concentration creams were prepared. Beeswax, paraffin wax, cetyl alcohol, and mineral oil were taken a china dish in a water bath $70^{\circ} \mathrm{C}$. Borax and the MECA extract were dissolved in purified water in a separate beaker in a water bath heated to $70^{\circ} \mathrm{C}$. The aqueous solution was added to the oily mixture slowly with continuous mixing in $-4^{\circ} \mathrm{C}$ (refrigerated circulating water bath, Equibath- 8520) and packed in a suitable container. The cold cream composition of ingredients in Table 1 [10].

\section{Antimicrobial assay}

The antimicrobial assay performed for MECA cold cream was evaluated by agar well diffusion method. The pathogen E. coli - MTCC293, MRSA - ATCC43300, VREF - ATCC51299, and C. albicans - MTCC7315 were cultivated in Muller-Hinton broth (Hi-Media). Fresh overnight cultures were used for this investigate. A 15-ml, Muller-Hinton agar was poured in well-rinsed autoclaved Petri plates and culture was spread

Table 1: Basic ingredients of cold cream prepared using herbal extracts (FCA refers to $C$. adscendens var. attenuata)

\begin{tabular}{llll}
\hline Ingredient & \multicolumn{2}{l}{ Concentration in grams } \\
\cline { 2 - 4 } & F1 & F2 & F3 \\
\hline FCA extract & $50 \mathrm{mg}$ & $100 \mathrm{mg}$ & $200 \mathrm{mg}$ \\
Beeswax & $1.12 \mathrm{~g}$ & $1.12 \mathrm{~g}$ & $1.12 \mathrm{~g}$ \\
Mineral oil & $6.86 \mathrm{ml}$ & $6.86 \mathrm{ml}$ & $6.86 \mathrm{ml}$ \\
Paraffin wax & $0.98 \mathrm{~g}$ & $0.98 \mathrm{~g}$ & $0.98 \mathrm{~g}$ \\
Cetyl alcohol & $0.14 \mathrm{~g}$ & $0.14 \mathrm{~g}$ & $0.14 \mathrm{~g}$ \\
Borax & $0.06 \mathrm{mg}$ & $0.06 \mathrm{mg}$ & $0.06 \mathrm{mg}$ \\
Purified water & $6 \mathrm{ml}$ & $6 \mathrm{ml}$ & $6 \mathrm{ml}$ \\
\hline
\end{tabular}

FCA: Formulated cold-cream C. adscendens var. attenuate. C. adscendens: Caralluma adscendens on the surface of the plate uniformly. After 15 min the well ( $5 \mathrm{~mm}$ ) punched on the plates with using cork bore. Then, we a pinch of freshly prepared cream put it inside the well, positive control used Neosporin, and negative control was dummy cream (without MECA cold cream). Then, the plate transferred to incubate at $37^{\circ} \mathrm{C}$ for $24 \mathrm{~h}$. The zone of inhibition was decided by measuring the diameter of the zone area. The well ( $5 \mathrm{~mm}$ ) showing no zone of inhibition and it considers as the no antimicrobial activity. All experiment was carried triplicated.

\section{Statistical analysis}

Statistical analysis was performed using one-way analysis of variance. All statistical analyses were used in SPSS package version 21.0 (IBM corporation, Armonk, New York) with using post-hoc comparison. $\mathrm{p}<0.05$ was considered statistically significant.

\section{RESULTS AND DISCUSSION}

Characterization of phytocompounds and creams formulation The MECA crude possesses a mixture of phytocompounds that include alkaloids, carbohydrates, flavonoids, steroids, terpenoids, phenols, glycosides, tannins, and phlobatannins Table 2 . Then, we formulated the cold cream at $50 \mathrm{mg}, 100 \mathrm{mg}$, and $200 \mathrm{mg}$ concentration. The cold cream color has been based level of drug pale green to dark greenish and empty cold cream has no color shown in Fig. 1. The wild succulent genus of Caralluma crude is having rich in phytoconstituent and its more pharmacological activity [11,12]. However, phytocompounds are not used direct topical apply for infected wounds that induce some allergen for skin [13]. Hence, we need herbal formulated antimicrobial cold cream having the potential to against the bacteria and fungi and its restricting side effects of the skin.

\section{Antimicrobial analysis of cold cream}

According to previous reports, various solvent succulents demonstrated antimicrobial activity against different microorganism [14]. Antimicrobial activity of cold cream containing biofabrication of MECA crude, on the other hand, negative control cold cream containing without extract of MECA and Neosporin, is used as the positive control. The antimicrobial activity of zone inhibition on the bacterial and fungal strain has significantly increased by Neosporin (market available cream) and formulated cold creams.

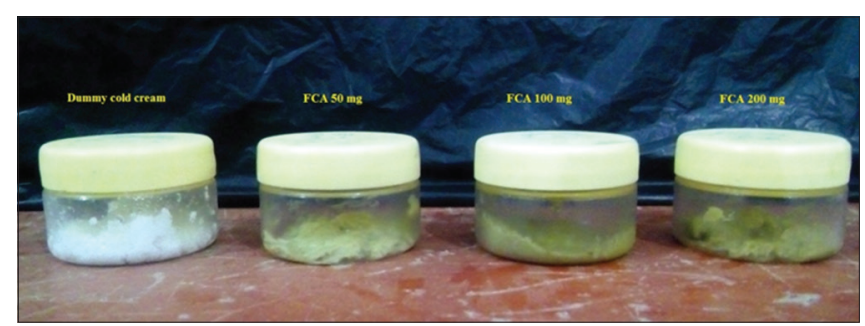

Fig. 1: Cold cream prepared using methanolic extract Caralluma adscendens var. attenuata (MECA) for three concentration

$50 \mathrm{mg}, 100 \mathrm{mg}$, and $200 \mathrm{mg}$. The dummy creams were made all ingredients and except herbal extract of MECA

Table 2: Preliminary phytochemical analysis of MECA (+ indicate the presence, - indicate the absence)

\begin{tabular}{ll}
\hline Test & MECA \\
\hline Alkaloids & + \\
Carbohydrates & + \\
Cardiac glycosides & + \\
Flavonoids & + \\
Steroids & + \\
Phenols & + \\
Tannins & + \\
Terpenoids & + \\
Phlobatannins & + \\
\hline
\end{tabular}

MECA: Methanolic extract C. adscendens var. attenuate. C. adscendens: Caralluma adscendens 
However, this not observed in dummy cold cream Fig. 2. Some of the authors reported the Neosporin is highly active against common wound pathogens such as MRSA, C. albicans, and Pseudomonas aeruginosa [15]. The post-hoc comparison that reveled the $200 \mathrm{mg}$ formulated cold-cream C. adscendens var. attenuata (FCA) has highly efficient to increase the zone inhibition compared with Neosporin $(\mathrm{p}<0.05)$. Further, it was compared to $100 \mathrm{mg}$ FCA and $50 \mathrm{mg}$ FCA and highly significant difference with dummy cream ( $p<0.01$ ) (Fig. 3). Methanolic extract of Caralluma fimbriata

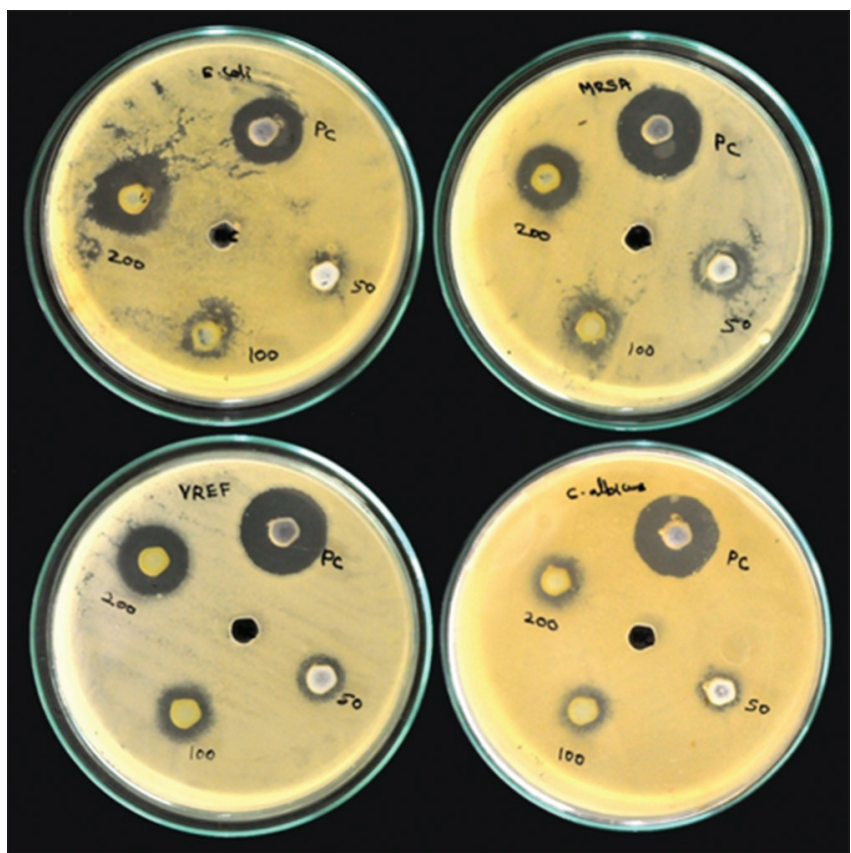

Fig. 2: The photographic image showed that the zone of inhibition (mm) observed around the well-containing creams. PC-positive control Neosporin, 50-cold cream 50 mg concentration, 100-cold cream $100 \mathrm{mg}$, and 200-cold cream $200 \mathrm{mg}$, and NC-negative control - dummy creams (loaded in the center well each plate and no zone formation)

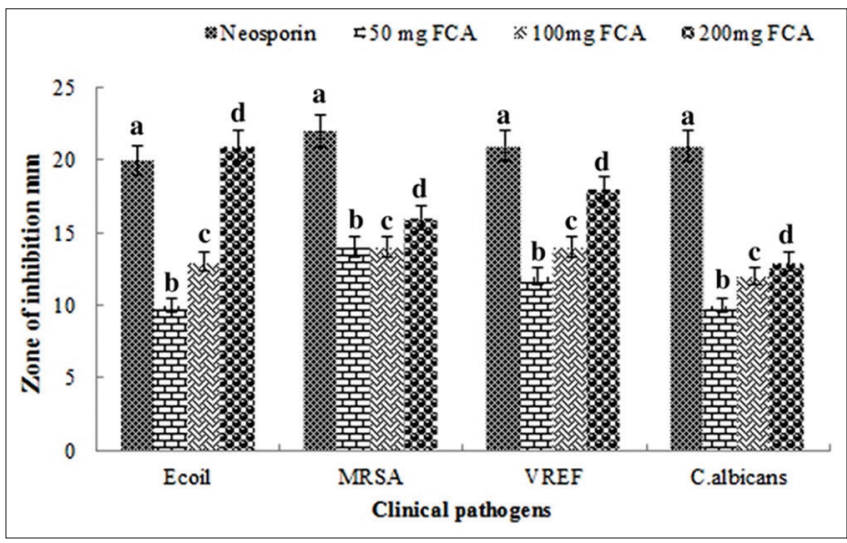

Fig. 3: The statistical graph represented the zone of inhibition (mm) around the well-containing cream. The Group I-a,

Group II-b, Group III-c, and Group IV-d. Labels indicate $(\mathbf{p}<\mathbf{0 . 0 5})$ significant difference, and $(\mathrm{p}<0.01)$ as a highly significant difference. One way analysis of variance with post-hoc testing

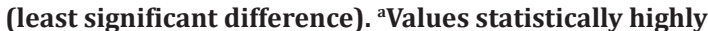
significant difference $(\mathrm{p}<0.01)$ when compared to Group II values. ${ }^{b}$ Values statistically significant difference $(p<0.05)$ when compared to Group III values. 'Values statistically significant difference $(p<0.05)$ when compared with Group IV values. ${ }^{d}$ Values statistically significant difference $(p<0.05)$ when compared with Group I values and Caralluma nilagiriana crude against the high activity of $P$. aeruginosa, E. coli, and S. aureus to induce the high zone of inhibition in compare with aqueous extract $[16,17]$. The biosynthesized silver nanoform flower extract to formulated cold cream has induced high zone inhibition to $E$. coli and MRSA [18]. Moreover, methanolic, ethanolic, and aqueous extract $C$. fimbriata against to fungi. In this study of $C$. adscendens var. attenuate had limited sense. However, the antifungal efficacy of cold cream treated against $C$. albicans has not been reported so far. We are a primary study to report the cold cream prepared from MECA had superior senescence - zone of inhibition to against $C$. albicans and other clinical pathogens. In this present study, to demonstrate the cold cream, MECA has an adverse effect against the clinical pathogen.

\section{CONCLUSION}

This work explores the efficacy of cold cream formulation with C. adscendens var. attenuate crude as the bases. However, this cold cream is against to E. coli, MRSA, VREF, and C. albicans antimicrobial activity for the presence of MECA crude phytoconstituents such as alkaloids, terpenoids, phenol, steroids, and glycoside. These phytochemicals had the potential to ameliorative effect on the clinical pathogens, increased the zone of inhibition. Further studies being going on examined the animal models; it is to bring the formulated cold cream on the market against fungal pathogenic infection on a skin wound.

\section{ACKNOWLEDGMENTS}

The authors are thanks to the Department of Pharmacognosy, Sankaralingam Bhuvaneswari College of Pharmacy, Sivakasi, for the great contribution to preparation cold cream for this study.

\section{AUTHORS' CONTRIBUTIONS}

The idea was conceived by the corresponding author (KL); the experimental part of the work was duly carried out by the first author (MS); and the technical studies were carried out, obtaining the guidance of the second author (SS).

\section{CONFLICTS OF INTEREST}

The authors declare that there are no conflicts of interest.

\section{AUTHORS' FUNDING}

The research work done by authors by the self-financial scheme and no financial support received from any funding agencies.

\section{REFERENCES}

1. Fabricant DS, Farnsworth NR. The value of plants used in traditional medicine for drug discovery. Environ Health Perspect 2001;109:69-75.

2. Balloux F, Van Dorp L. Q\&A: What are pathogens, and what have they done to and for us? BMC Biol 2017;15:2-6.

3. Findley K, Grice EA. The skin microbiome: A focus on pathogens and their association with skin disease. PLoS Pathog 2014;10:1-3.

4. Pujji OJ, Nakarmi KK, Shrestha B, Rai SM, Jeffery SL. The bacteriological profile of burn wound infections at a tertiary burns center in Nepal. J Burn Care Res 2019;40:838-45.

5. Enioutina EY, Teng L, Fateeva TV, Brown JC, Job KM, Bortnikova VV, et al. Phytotherapy as an alternative to conventional antimicrobials: Combating microbial resistance. Expert Rev Clin Pharmacol 2017;10:1203-14.

6. Kumar KM, Murshida UC, Thomas B, George S, Balachandran I, Karuppusamy S. Notes on Caralluma adscendens (Roxb.) Haw. var. attenuata (Wight) Grav. \& Mayur. (Apocynaceae: Asclepiadoideae). J Threat Taxa 2014;6:6282-6.

7. Kiranmayee P, Anitha K, Usha R. Isolation and identification of steroid triterpenoids from the polar and non-polar fractions of Caralluma attenuate (Weight) roots. Int J Pharmacogn Phytochem Res 2016; 8:912-29.

8. Raman N. Phytochemical Methods. New Delhi: New Indian Publishing Agencies; 2006. p. 19

9. Shamaki BU, Geidam YA, Abdulrahma F, Ogbe AO, Sandabe UK. Evaluation of phytochemical constituents and in vitro antibacterial 
activity of organic solvent fractions of Ganoderma lucidum methanolic extract. Int J Med Plant Res 2012;1:26-31.

10. Carter SJ. Cooper and Gunn's Dispensing for Pharmaceutical Students. $12^{\text {th }}$ ed. Edinburgh: Churchill Livingstone; 1896. p.159.

11. Pavan Kumar B, Ashok G, Mohammed I, Ramachandra NM, Rashmi KP. Pharmacognostic evaluation of selected species of Caralluma genus. J Phytopharmacol 2015;4:34-40.

12. Noreen S. A mini review on a Caralluma tuberculata N. E. Br. uncommon and wild succulents but having exciting pharmacological attributes. Pure Appl Biol 2017;6:748-61.

13. Khémiri I, Hédi BE, Zouaoui NS, Ben Gdara N, Bitri L. The antimicrobial and wound healing potential of Opuntia ficus indica L. inermis extracted oil from Tunisia. Evid Based Complement Altern Med 2019;2019:1-10.

14. Prakoso YA, Rini CS, Wirjaatmadja R. Efficacy of Aloe vera, Ananas comosus, and Sansevieria masoniana cream on the skin wound infected with MRSA. Adv Pharmacol Sci 2018;2018:4670569.

15. De Silva CC, Israni N, Zanwar A, Jagtap A, Leophairatana $P$, Koberstein JT, et al. "Smart" polymer enhances the efficacy of topical antimicrobial agents. Burns 2019;45:1418-29.

16. Prabakaran R, Kalimuthu K. Antibacterial activity of the whole plant of Caralluma nilagiriana Kumari et Subba Rao-an endemic medicinal plant species. Int J Pharm Bio Sci 2013;4:42-8.

17. Packialakshmi N, Naziya S. Phytochemical and antimicrobial screening of the polar and non-polar solvent stem extract of Caralluma fimbriyata. Int J Pure Appl Biosci 2014;2:32-7.

18. Sahana R, Daniel SC, Sankar SG, Archunan G, Vennison SJ, Sivakumar M. Formulation of bactericidal cold cream against clinical pathogens using Cassia auriculata flower extract-synthesized Ag nanoparticles. Green Chem Lett Rev 2014;7:64-72. 